\title{
DISCONTINUITY OF KNOWLEDGE*
}

\author{
Volkan YÜCEL ${ }^{1}$
}

\begin{abstract}
Michel Foucault and Thomas Kuhn concerned with the discontinuity of discourse in the sciences and social disciplines. In 1960s, Kuhn expressed that the natural science reflects in a general sense a sequence of paradigm changes. In 1970s, Foucault claimed a type of discourse about the advancement of scientific knowledge in an extent of human and medical sciences. They both discovered convincing and compelling discontinuities in the history of science and knowledge. The archaic exploration of human knowledge is significant in this appreciation. 'The power' linked to reality (the truth) and discourse is the essential driver in this progression. There is reliably a shift in focus while keeping up, conveying and making our structures of convictions (doxa) and feelings. Foucault and Kuhn clarify the extent of "knowledge/discontinuity" principle through separating connections of power on knowledge from the incomparable truth.
\end{abstract}

Keywords: Foucault, Kuhn, Discontinuity, Episteme, Paradigm

\section{BİLGINIIN SÜREKSİZİ̈̆̇̇}

ÖZ

Michel Foucault ve Thomas Kuhn, bilim ve sosyal disiplinlerdeki söylem süreksizlikleriyle ilgilenmiştir. 1960'larda Kuhn doğa bilimlerinin aslında bir paradigma değişimi sekansını yansıttığını belirtir. 1970'lerdeyse Foucault insan bilimleri ve tıp alanındaki bilimsel bilginin gelişiminin bir söylem çerçevesine sahip olduğunu savunur. Her iki düşünür de bilgi ve bilim içerisindeki uç süreksizlikleri tespit etmiştir. Bu açıdan insan bilgisinin arkaik keşfi önemlidir. Gerçeğe ve söyleme bağlanan ‘iktidar’; mevcut süreksizliklerin nedenidir. 'Kanı' (doxa) sistemleri üretir, yaratır ve desteklerken mutlaka bir odak kayması oluşmaktadır. Foucault ve Kuhn, mutlak gerçeklik ve bilgi üzerindeki iktidar ilişkilerini birbirinden ayırt ederek bilgi ve süreksizlik doktrininin kapsamını da açık etmiştir.

Anahtar Sözcükler: Foucault, Kuhn, Süreksizlik, Episteme, Paradigma

\section{Introduction}

Social or natural sciences use diverse methodologies while applying their theories to the reality, nature and society. The natural sciences depend on a distinct mathematical ontology (Bailly and Longo, 2011: 28) and a scientific philosophy. Science and particularly natural concepts and ideas have been criticized by philosophy all through history (Paseau, 2011; Keren, 2011: 1-2) on the base that mathematics (arithmetic) has its own particular metaphysics which concludes in discontinuities.

Makale Gönderim Tarihi: 02.02.2016 ; Makale Kabul Tarihi : 23.03.2016

${ }^{1}$ Asst. Prof., Beykent University, Department of Sociology, vlknycl gmail.com. 


\section{BUJSS}

10/1 (2017), 87-96

The naturalist stance charges us to acknowledge mathematical substances as a feature of our philosophical premise:

The theories of the natural sciences appear to be less certain and more open to revision than mathematical theories. For these reasons, mathematics poses problems of a quite distinctive kind for philosophy. Therefore, philosophers have accorded special attention to ontological and epistemological questions concerning mathematics. ... Then Kurt Gödel proved that there exist arithmetical statements that are undecidable in Peano Arithmetic. This has become known as his Gödel's first incompleteness theorem. ... Gödel then quickly realized that, unless (God forbid!) Peano Arithmetic is inconsistent; the consistency of Peano Arithmetic is independent of Peano Arithmetic. This is Gödel's second incompleteness theorem. Gödel's incompleteness theorems turn out to be generally applicable to all sufficiently strong but consistent recursively axiomatizable theories. ... If we take the mathematics that is involved in our best scientific theories at face value, then we appear to be committed to a form of Platonism. However, it is a more modest form of Platonism than Gödel's Platonism. For it appears that the natural sciences can get by with (roughly) function spaces on the real numbers. The higher regions of transfinite set theory appear to be largely irrelevant to even our most advanced theories in the natural sciences. ${ }^{2}$

There is a solid naturalistic attitude in mathematics asserting that mathematical theories are observational and empirical which called as indispensability argument (Colyvan, 2001). Indeed, a few researchers in the way that our best theory of knowledge is the causal theory of knowledge deny Gödel's incompleteness theorems (Gödel, 1967) and his contentions directed against the accounts of mathematical intuition. In any case, on the off chance, that we assume that reliabilism is the best theory of knowledge, and then the issue would get to clarify how one can succeed in getting reliable beliefs about mathematical entities. This inquiry is just open not to natural science, rather additionally to social disciplines.

In this sense, T. Kuhn and M. Foucault are very imperative figures found a more noteworthy number of discontinuities in the history of science. Their perspectives are extreme in this appreciation. Science can keep itself thriving and growing through its huge establishments and can legitimize itself through its service given to general society. Both Kuhn and Foucault reprimanded the structure and authenticity of realism held by the great institution of science. T. S. Kuhn (1922-1996) is a standout amongst the most persuasive scholars of the science of the twentieth century. His 1962 book The Structure of Scientific Revolutions is one of the most refereed academic books ever. Kuhn's commitment to the rationality checked not just a break with positivism, additionally initiated another style of philosophy of science that conveyed it nearer to the historical backdrop of science. To this proposition, Kuhn included the dubious 'incommensurability postulation',

2 "Philosophy of Mathematics", 02.05.2012, Stanford Encyclopedia of Philosophy. Retrieved from January 11, 2016 from http://plato.stanford.edu/entries/philosophy-mathematics.

3 “T. Kuhn", 11.08.2011, Stanford Encyclopedia of Philosophy. Retrieved from January 12, 2016 from http://plato.stanford.edu/entries/thomas-kuhn. 


\section{BUJSS}

10/1 (2017), 87-96

that theories from contrasting periods experience the ill effects of certain profound sorts failure of comparability. As indicated by Kuhn himself (1970, 307-35), The Structure of Scientific Revolutions initially stimulated enthusiasm among social researchers, despite the fact that it did on the appointed course create the interest among philosophers that Kuhn had intended.

M. Foucault (1926-1984) is a French historian, connected with the structuralist and post-structuralist movements. He has had the primary influence in philosophy as well as in an extensive variety of humanistic and social scientific disciplines. G. Canguilhem, a figure in the French University, whose work in the history and theory of science gave a model to quite a bit of what Foucault was later to do in the historical backdrop of the human sciences. Canguilhem supported Foucault's doctoral proposal on the history of madness and, all through Foucault's career, stayed one of his imperative and viable supporters. Canguilhem's methodology created from the work of Gaston Bachelard to the history of science provided Foucault with a solid sense of the discontinuities in scientific history, alongside a "realistic" comprehension of the historical role of ideas that made them autonomous of the phenomenologists' transcendental consciousness. This philosophical milieu gave materials to the evaluate of subjectivity and the corresponding archaeological and genealogical" strategies for writing history that informs Foucault's tasks of historical investigate.

Kuhn has an alternate purpose of perspectives on the history and rationality of science. As per exploratory comprehension and scientific understanding of modernity, scientific advancement is aggregate. Scientific knowledge is just real information. There is no support for standardizing hypothesis, normative theory viewpoint and value judgments in data evaluation and hypothesizing. Legitimate assessment and knowledge can be achieved just by utilizing rationale, statistics and mathematics. The motivation behind the science is uncovering cause and effect relationships. Kuhn censures this positivist scientific methodology and logical approach. To him, (1) science is not immaculate and objective and (2) it advances with breakups and the revolutions that are not combined.

He advocates that every science is to be re-assessed in its historical connection as opposed to looking at its contributions left. Science goes starting with one paradigm, then onto the next one with revolutions like social and political occasions.

Social sciences use diverse procedures while applying their hypotheses to reality. The common sciences rely on a specific philosophy. Science and especially typical thoughts have been scolded by theory all through history on the base that arithmetic has its own transcendentalism that shut in discontinuities.

T. Kuhn and M. Foucault are basic figures found a more noticeable number of discontinuities in science. Their perspectives are extremely convincing in this appreciation. Science can keep itself flourishing 


\section{BUJSS}

10/1 (2017), 87-96

and reaching out through its massive foundations and can legitimize itself through its organization given to the all-inclusive community.

\section{Stages of Scientific Revolutions}

Kuhn depicts three phases in the advancement of sciences. In pre-science stage, numerous opinions on the nature compete with each other. Incomplete, incompatible and distinctive theories exist together. There is no agreement on a particular theory. At some point, one of these theories overpowers the others and it turns into the predominant viewpoint. This is the start of a normal science. The prevailing hypothesis must be responsible to happen a worldview.

Kuhn says, "Normal science means research firmly based upon one or more past scientific achievements" (Kuhn, 1970: 10). This stage completed inside a paradigm. As per Kuhn, there are two crucial attributes of ideal paradigms accepted as a normal science. Their accomplishment was adequately remarkable to draw in a continuing group of adherents far from contending methods of scientific activity. All the while, it was sufficiently open-ended to leave a wide range of issues for the redefined group of practitioners to resolve (Kuhn, 1970: 10).

In this stage, scientists are like a man solving a puzzle. They use the paradigm as a guide to clear up the problems. An anomaly, the fact which cannot be solved by the paradigm, arises over time. The inadequacies of the dominant paradigm come to light as long as the numbers of anomalies increase. However, not all anomalies cause a paradigm to be rejected. They must be severe, prolonged, and harder to ignore. This causes a sense of crisis and scientists research alternative theories. Thus, science moves to the third stage.

In revolutionary science, one of the alternative theories succeeds and it becomes the new paradigm by way of paradigm shift. Thus, scientific revolution comes true. In scientific revolution, one paradigm replaced by another and normal science continues until new anomalies emerge and they trigger the new crisis.

\section{Paradigm}

Kuhn defines the paradigm in the preface as “... universally recognized scientific achievements that for a time provide model problems and solutions to a community of practitioners" (Kuhn, 1970: viii). However, M. Masterman says that Kuhn uses the paradigm as 21 different meanings in three groups, but they do not conflict with each other. These meanings are:

... a universally recognized scientific achievement; (2) a myth; (3) a 'philosophy', or constellation of questions; (4) a textbook, or classic work; (5) an whole tradition, and in some sense, as a model; (6) a scientific achievement; (7) an analogy; (8) a successful metaphysical speculation; (9) an accepted device in 


\section{BUJSS}

10/1 (2017), 87-96

common law; (10) a source of tools; a standard illustration; (12) a device, or type of instrumentation; (13) an anomalous pack of cards; (14) as a machine-tool factory; (15) a gestalt figure which can be seen in two ways; (16) a set of political institutions; (17) a "standard" applied to quasi- metaphysics; (18) an organizing principle which can govern perception itself; (19) a general epistemological viewpoint; (20) a new way of seeing, (21) something which defines a broad sweep of reality. (Kuhn, 1970: 61-65).

A paradigm is composed of some generalizations, assumptions, values and exemplars:

Symbolic generalizations: They are premises reminiscent of the laws of nature. These statements cannot be tested. For instance, Newton's second law or Ohm's law.

Metaphysical assumptions: It includes beliefs such as gas molecules behave like small and flexible billiard balls that moving randomly.

Values: The values are considered in here are as quantitative predictions are better than qualitative predictions and theories should be simpler and more consistent.

Exemplars: Scientists learn to solve a series of standard problems and to make a series of standard tests during their training and thus they begin to see objects and events with a common perspective, which is impossible to summarize. They acquire tacit knowledge and adopt common examples.

For a scientific revolution, scientists abandon one paradigm in favor of another. Once a new paradigm emerges, science is resumed, the frame of the new paradigm begins to be worked out and it continues until a new batch of anomalies emerges. The paradigm shift is like a gestalt switch as in the duck/rabbit image below:

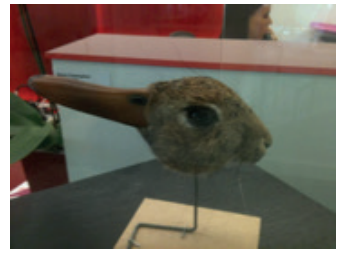

\section{Duck/Rabbit Image ${ }^{5}$}

Seeing this image as a rabbit blocks out to see it as a duck. It is same for the paradigm shift. In a paradigm, conceptual frameworks can repeatedly change in favor of another.

\section{Incommensurability}

According to Kuhn, there is a scientific change but not a scientific progress or development. Progress could be only possible in the process of normal science (paradigm). He suggests that the very meaning of the paradigm can only be comprehended up to the framework of that paradigm. In this sense, paradigms are incommensurable (lacking independent standard of a common measure). 


\section{BUJSS}

10/1 (2017), 87-96

Different aspects of incommensurability can be grouped in four titles:

No neutral language: Different paradigms use different languages. Even if they include the same vocabulary, they use it in different contexts. Their theoretical frame can affect the meanings of the terms. Therefore, we cannot create neutral definitions of terms used by different theories.

No neutral observations: Our observations depend on our theoretical commitments. Our theories affect what we see. Two competing theories make conflicting observational predictions.

No neutral criteria for theory choice: There is not a good way to define the true theory. "In learning a paradigm the scientist acquires theory, methods, and standards together, usually in an inextricable mixture ... each paradigm will be shown to satisfy more or less the criteria that it dictates for itself and to fall short of those dictated by its opponent" (Kuhn, 1970: 110).

No neutral world: This is the extremist claim Kuhn makes. Scientists live in different worlds of experience and they changed when their theoretical frames change. For instance, until the medieval period, there were no pendulums, but only swinging objects (Brown, 2011).

Seeing this picture as a rabbit shut out to consider it a duck. It is same for the outlook change. In a worldview, conceptual structures can over and over change for another.

\section{Foucault's Episteme}

An episteme allows thoughts to be organized yet limits the experience, truth, and governs each knowledge in a period. Each historical period has its own episteme. The concept of the episteme is an important to Foucault. It is a priori, but its meaning is different from Plato's episteme. "According to Plato, episteme is true, eternal and compulsory a priori knowledge which contains discursive knowledge (dianoia) and comprehension related to ideas (nous) in it" (Cevizci, 1999: 306). Foucault introduces his episteme concept in The Order of Things. There are discussion and confusion about what is the exact meaning of his notion. He uses different definitions. Foucault defines the concept of episteme in The Archeology of Knowledge: The episteme is not a form of knowledge (connaissance) or type of rationality which, crossing the boundaries of the most varied sciences, manifests the sovereign unity of a subject, a spirit, or a period; it is the totality of relations that can be discovered, for a given period, between the sciences when one analyses them at the level of discursive regularities (Foucault, 1972: 191). In Power and Knowledge, episteme is defined as; "I would define the episteme retrospectively as the strategic apparatus which permits of separating out from among all the statements which are possible those that will be acceptable within, I won't say a scientific theory, but a field of scientificity, and, which it is possible to say are true or false. The episteme is the 'apparatus' which makes possible the separation, not of tile true from the false, but of what may from what may not be characterized as scientific." (Foucault, 1980: 197). 


\section{BUJSS}

10/1 (2017), 87-96

Foucault tries to determine rules and acceptance of the possibility of knowledge. These rules, which are special to discursive regions and ever-changing in the history, constitutes episteme that represents experimental orders and common practices of a historical period or basic codes of a culture that constructs the form of knowledge.

Foucault believes every statement as an ingredient of a discourse must be taken in its historical dispersion and uniqueness (Foucault, 1972: 30). Episteme is the sum of the relationship between sciences, epistemological forms, positivity and discursive practices. It is not a synonym of knowledge, it is the expression of the principles that exist before a scientific discourse is regulated and knowledge independent from discourse put in the historical order.

\section{Types of Episteme}

Foucault's archaeological inquiry in The Order of Things distinguishes three epistemic systems: the Renaissance, the classical age and modernity (Oksala, 2005: 21). ${ }^{6}$ These ages are archaeological rather than historical. Foucault is interested in the texts related to its era rather than their discourse. Hence, layers are identified in a temporal continuum; each layer is an episteme. The notion of the episteme is kind of a tool for understanding the historical conditions of possibility of knowledge in a particular period (Oksala, 2005: 21). Episteme refers to the historical conditions of possibility, so the priori of an epoch.

The Renaissance Episteme (16th century): Everything resembles something else and in that sense stands for it. Knowledge consists of interpretation and resemblances. It is additive and analogical moving between microcosm and macrocosm. There is no distinction between sign and object. They are read as signs relating to other signs. The world is read as a book (Miel, 1973: 236).

The Classical Episteme: With the 17th century, all this is changed. The nature of knowledge itself has changed and the new episteme outlived the success of Cartesian mechanism. No further significant change happened in the episteme until the 18 th century.

The theory of signs emerged through distinction. In the construction of a grammar, in the taxonomy of history, and in the analysis of wealth, money is essentially a sign and therefore can be related to human knowledge and even human desire, but not to the means of production (Miel, 1973: 236).

The Modern Episteme (19th century): The sciences of man are born. The wealth analysis becomes economics, linguistics becomes philology, and history becomes biology. To Foucault, humanity is now at the end of this period. They are to awaken from their anthropological sleep, ideology or dogmatism. However, Foucault does not tell what the new episteme will be (Miel, 1973: 237).

6 "The episteme determines the possibilities and limits of any period or context; and when these possibilities have been realized, when the space has been saturated, then a break occurs and a new episteme is born, with the process beginning anew. Las Meninas 'represents' the entire cycle of this process as well as the opening which will lead to the formation of a new episteme." (Carroll, 1978: 707) 


\section{BUJSS}

10/1 (2017), 87-96

Foucault uses the concept of 'episteme' to refer to the historical context of an age when the social sciences have emerged (Birkin and Polesie, 2011: 239) in The Order of Things (1970). The episteme is the subject of archeological consciousness, the only true consciousness for Foucault. The first problem, however, is to locate the episteme, since it is not conscious to an individual or collective subject:

The discourse of the Classical Order began with the Enlightenment promise and exciting prospect of success in finding the essential order of things; it grew to the threshold of that supreme act of nominalization of everything, and akin to the Tower of Babel reached its dizzy heights, but fell short of its goal and came crashing down in the nineteenth century. (Rogers, 2012: 5)

The episteme, like the truth, is one; by definition, there can only be one episteme for each period. The "oneness" of each episteme determines a full space contemporaneous or present to itself, the context and frame of presence. (Carroll, 1978: 710). The discourse of the Classical episteme reached its limit in the 19th century.

\section{Conclusion}

Foucault's epistemes are different from Kuhn's paradigms, but they share some commons. They do not correspond to conscious principles, like those by Newton, providing a model for scientific activity; they are rather in the level of reasoning. Kuhn's paradigms are 'exemplars'. They operate in scientific practice. They are more than theory, but less than a worldview. Paradigms are largely implicit and they belong more to practice than to a scientific collective unconscious.

Paradigms are not exactly rules; but epistemes are definite rules. They are codes, grammars of cognitive language. The two ideas are in two different levels: paradigms are not simple theories and epistemes are not world opinions. Yet Foucault's epistemes are like Kuhnian paradigms in two respects: (1) they are 'incommensurable', (2) they perish in response to cultural changes not to contrary evidences. Another similarity of Kuhnian account of "paradigm” with Foucauldian philosophy:

"Preparadigmatic period is also prescientific period where diverse schools function on the basis of competing fundamentals and operating styles such that only with the advent of a paradigm these conflicts can be suppressed in the sense that "normal science" reaches "maturity" and operates without questioning its fundamentals and rejects what is not assimilated into these fundamentals as non-scientific." (Karademir, 2009: 98-9)

For Kuhn, paradigms are particular and historical models for scientific practices to formulate laws in particular forms, to use particular instruments, to appeal particular verification criteria, and to apply theories in particular ways (Karademir, 2009: 98). 


\section{BUJSS}

10/1 (2017), 87-96

Kuhn's idea of scientific revolutions preceded by some concept crisis, so Foucault tells the shortcomings of two epistemes: the modern and the classical. There is, nevertheless, a last, important difference: Kuhnian crises fight each other in a true struggle for life, although the final victory of one of them stems from extra-rational causes (Merquior, 1985: 38). As Foucault ascribes the emergence of the criterion of verification to historical a priori, Kuhn suggests that it is the paradigm that leads scientists to use and validate particular puzzle-solution tactics and instrumentation (Karademir, 2009: 99).

Foucault writes, for example; "In any given culture and at any given moment, there is only one episteme that defines the conditions of possibility of all knowledge, whether expressed in a theory or silently invested in a practice" (Foucault, 2005: 183).

Overall, Foucauldian views are akin to those of Kuhn (Nola \& Irzik, 2005: 343). Kuhn (in 1960s) argued that the science (mainly natural science) is marked by a sequence of paradigm changes. Foucault (in 1970s) advanced a discourse about the growth of scientific knowledge in a range of human and medical sciences. They both located a great number of extreme discontinuities in the history of science. The archaeology of human knowledge is meaningful in this respect. The power linked to truth or discourse is the main cause in this continuities. There is always a shift in focus while maintaining, producing and creating our system of beliefs. Foucault and Kuhn make clearer the scope of "knowledge/discontinuity" doctrine through separating relationships of power on knowledge from the absolute truth.

\section{REFERENCES}

Bailly, F. \& Longo, G., (2011) Mathematics and the Natural Sciences: The Physical Singularity of Life. London: Imperial College Press.

Benacerraf, P., (1973), 'Mathematical Truth', in Benacerraf \& Putnam 1983, 403-420.

Birkin, F. and Polesie, T., (2011), An Epistemic Analysis of (Un)Sustainable Business. Journal of Business Ethics, 103, 239-253.

Brown, C., (2011), Philosophy of Science: Some Notes on Kuhn's Structure of Scientific Revolutions. Retrieved from January 10, 2016 from http://www.trinity.edu/cbrown/science/kuhn.html.

Carroll, D., (1978), The Subject of Archeology or the Sovereignty of the Episteme. MLN, 93(4), $695-722$.

Cevizci, A., (1999), Felsefe Sözlüğü. İstanbul: Paradigma.

Colyvan, M., (2001), The Indispensability of Mathematics, Oxford: Oxford University Press.

Foucault, M., (1972), The Archeology of Knowledge. New York: Pantheon.

_ (1980), Power/Knowledge: Selected Interviews and Other Writings, 1972-ᄀ1977. Ed. Colin Gordon. New York: Pantheon. 


\section{BUJSS}

10/1 (2017), 87-96

_ (2005), The Order of Things. London: Routledge.

Gödel, K., (1967), ‘On Formally Undecidable Propositions in Principia Mathematica and Related System I', in van Heijenoort, 596-616.

Guilherme, J,. (1985), Foucault. Los Angeles: University of California.

Karademir, A., (2009), Foucault, Sexuality, and an Epistemico-Ontological Ground for Resistance (Master's thesis, METU, Ankara, Turkey). Retrieved from https://tez.yok.gov.tr/UlusalTezMerkezi/TezGoster?key=7d53ed97e31a8bd3e031db4041bf44dbba3b1399f83194a4a3e76cba9a526407c2f6efe8700d bbeb.

Keren, A., (2011), "Psycho-Mathematical-Ontology", 05.11.2011. Retrieved from January 12, 2016 from https://www.academia.edu/1136015/Psycho-Mathematical-Ontology.

Kuhn, T. S., (1970), The Structure of Scientific Revolutions. Chicago: University of Chicago.

Masterman, M., (2004), The Nature of a Paradigm. In I. Lakatos and A. Merquior, (Ed.), Criticism and the Growth of Knowledge. London: Cambridge University.

Miel, J., (1973), Ideas or Epistemes: Hazard versus Foucault. Yale French Studies, 49, 231-245.

Nola, R. \& Irzik, G., (2005), Philosophy, Science, Education and Culture. Dordrecht: Springer.

"Philosophy of Mathematics", 02.05.2012, Stanford Encyclopedia of Philosophy. Retrieved from January 11, 2016 from http://plato.stanford.edu/entries/philosophy-mathematics.

Oksala, J., (2005), Foucault on Freedom. New York: Cambridge University.

Paseau, A., (2011), "Naturalized philosophy of mathematics", Routledge Encyclopedia of Philosophy, DOI: $10.4324 / 9780415249126-Y 094-1$

Rogers, K., (2012), On Foucault's Discourse. Los Angeles: Trébol. 